\title{
Policy Implications on Local Government Expenditure in Sri Lanka
}

\author{
S.R. Sepalika Nayanie Sudasinghe ${ }^{1}$ \\ SLJDA 2015 (5): 93-108
}

\begin{abstract}
Local governments are closer to the people especially in the context of democratic governance than other units of governments. 'Determinants of government expenditure' is therefore a recurring theme both in government and scientific discourse. This study intends to develop and test a comprehensive and systematic model on the allocation of government expenditures in urban councils in Sri Lanka to identify the key determinants of local government expenditure decisions. Therefore, the study considers three major perspectives, socio-economic, political and governmental and justifies the relevancy of models of expenditure determinant research. This is a research. The first premise is that local government expenditure varies on the mixture of socio-economic, political and governmental factors. More socio-economic variables in the model indicate a demand driven aspect in local government resource allocation. Local government's tax effort is a significant fact together with financial transfers from the central government in expenditure decision-making. As policy implications participatory budgeting system and strengthening of the local revenue base are proposed.
\end{abstract}

Key words: Determinants, Local government Expenditures, Sri Lanka.

\section{Introduction}

"Local governments are commonly accepted levels of democratic governance which have been actively engaged in local development activities in our country since historical times and provide basic services and development to citizens in the areas under its jurisdiction" (National policy on local government, p.1A). Therefore, 'determinants of government expenditure' is a recurring theme both in government and scientific discourse, such as in public economics and public finance literature. Most of these debates center on the question of the relevant importance of the determinants of government expenditure over one another. Identifying determinants is important because the local governments are closer to the people, especially in the context of democratic governance than other units of existing governments. Besides traditional responsibilities, urban governments presently encounter new

1 S.R. Sepalika Nayanie Sudasinghe Ph.D. in Development Administration (specialized in public policy management) is a Senior Consultant to the Sri Lanka Institute of Development Administration. Correspondence concerning this article should be addressed to Dr.

Sudasinghe, E-mail: Sepalikasudasinghe@yahoo.co.uk 
challenges due to the changing factors in which they operate. In this regard the urban local governments - in this study the municipalities and urban councils - encounter numerous challenges as service providers to their localities. Therefore, during the last couple of decades, a large number of studies have investigated government expenditure, given the importance of the subject matter in public economics, but these have scarcely been extended to developing countries.

Thus, research in the Asian context, specifically in the Sri Lankan context is vital as Sri Lanka has hardly examined this subject systematically.

Apart from the above, the local governments, specially the urban governments of Sri Lanka face a new generation of challenges due to the population growth and urbanization in the country. Therefore urban governments have many more customers to provide services for, than they did in the past. In this regard their responsibilities become broader and vital in terms of community well-being. Therefore identification of determining factors of fiscal allocation is vital for better service delivery.

Moreover, in Sri Lanka 8.9 \% of the population still live below the poverty line (Department of Census and Statistics, 2013). In this regard the assessments on government expenditure, especially on the local governments, offer several useful insights to policy makers to target the reduction of poverty. This is because when a government is closer to the people, better understanding of the needs and resources of their own jurisdictions lead to the supply of 'right' local public goods to meet the needs of the community. In that sense the identification of determinants that lead to fiscal decisions is vital. Therefore, the policy proposals are made considering Sri Lanka's current local government policy paper.

Presumably, in a broader sense this empirical research intends to explain the socio-economic, political dichotomy of the existing literature by integrating governmental perspective in modelling the expenditure decisions of the urban councils of Sri Lanka. In the light of the said explanation this study intends to develop and test a comprehensive and systematic model on the allocation of government expenditures in urban councils in Sri Lanka to identify the key determinants of local government expenditure decisions.

\section{Literature review}

Most studies explaining the determinants of government expenditure still follow the conventional pattern of examining the relative importance of socio-economic dominancy vis-à-vis political dominancy. Only a few 
studies can be seen to address the broader subject matter and consider other aspects such as institutional, demographic, and geographic factors. However, the following literature review explains the determinants of socio-economic, political and governmental factors affecting local government decision making in general.

Socio-economic impact embraces many possible impact dimensions -- economic, individual, social, and environmental. This approach basically assumes that the socio economic needs and resources are more influential in policy research.

The political approach as a determinant of government expenditure studies has become a common interest of political scientists. This approach is an instrument in assessing the local democracy as the elected politicians make decisions on behalf of local communities.

The governmental approach concerns the characteristics of the government and evaluates how decisive those factors are in forming public policies. In this regard, the substantial impact of bureaucracies on development and implementation of public policy is widely recognized and generally believed to be increasing (Downs \& Rocke, 1979). Therefore, the following literature review discusses the relevant models of the aforesaid approaches from the research studies in developing a model on the Sri Lankan context. Further, the following literature explains the evolution of models of expenditure decision making.

\section{Studies on the socioeconomic approach}

Fabricant and Fisher can be identified as the early economic determinists of this disciplinary perspective. Glen Fisher (1961) using the same variables of Economist Fabricant (1952) updated the findings on various expenditure categories and found the figures for explanatory variables that are lower than in Fabricant's work. (1953).

Sacks and Harris (1964) using the year 1960 expenditure data found declining power of the explanatory variables used in the areas of welfare and health. Ernest Kurnow (1963) used a joint effect regression model and criticized Fabricant (1952) and Fisher's (1961) additive model. Further Bahl and Sounders (1965) using a multiple correlation technique which is very similar to Kunow's method, explained the interstate variations in the changes in both per capita general expenditures and per capita expenditures by functions.

Extending the analysis of the effects of aid on government expenditures, Weicher (1972), investigated further the Osman (1966) and Smith (1968) 
findings on the effects of aid on expenditures for non-aided functions, in the areas where there is more than one government serving the same population. His results were consistent with those of Osman and Smith, and also with the model tested. Widening the research area into current and current plus capital outlays expenditures per capita, Gabler and Brest (1967), conducted a regression study on the functional relationship between per capita income of State and local government expenditures and various independent factors.

Later the political scientists highlighted the importance of economic variables and several political scientists seem to be employing the economic variables in their studies. During the same period economists also started to find additional variables in refining the basic models. Sjoquist, in 'The effect of the number of local governments on central city expenditures' (1982) explored the notion that local governments engage in strategic behaviour in an effort to retain the tax base.

Further to the aforesaid explanation Matteo and Matteo (1998), have used a determinants approach in examining the determinants of healthcare expenditures. Thereafter Poterba (1996) explored the relationship between expenditures with elementary education and demographic variables in American States during the period 1960-1990. Further, Fernandez and Rogerson (1997) also studied public expenditure on education in the American States using panel data for the period 1950-1990 and confirm the findings of Poterba (1996) concerning the drop in per-capita expenditure with respect to rises in the proportion of enrolments. As a study done in the recent past, Painter and Bae (2001) used a standard model in the literature to explain the State government expenditure. Further, a more recent study by Ponlapat (2011) adopted the demand-side and supply-side explanations to analyse the changes in public spending in Thailand during the period 1982-2003. Considering the explanatory variables used in the abovementioned models, population density, education and the health conditions of the local population and the level of commercialisation of the locality were considered in explaining the socio-economic aspect of the model relevant to the Sri Lanka..

\section{Studies on political approach}

Key and Lockards are among the early political determinists who emphasized the importance of political variables in modelling local government decision making. Key (1956) can be seen as the first political determinist who used explanatory variables such as party competition and political participation in their studies. Further, proposing a model similar to that of Key, Lockard (1963) used an economic development 
variable to explain the expenditure decisions and argued that a high level of economic development of a locality forms the high party competition which determines the level of expenditure. However, later, along with the theoretical contributions of Key and Lockard, Dawson and Robinson (1963) concluded a study on the same aspect and proved that socioeconomic conditions were more important than political variables such as inter-party competition in shaping welfare policies.

In studying the evolution of the models in the literature, it is seen that recovery from 'discipline myopia' had led political scientists to follow the concept measurement approach in refining the basic models of decision making on local contexts. Hofferbert (1966) took the first attempt in this manner in "Socioeconomic Dimensions of the American States, 1890-1960'. With a similar conclusion Hofferbert's work was extended by Sharkansky and Hofferbert (1969) by discussing the dimensions of State politics, economic and public policy. Further, Dye (1966) conducted a study on politics, economics and public policy and employed four economic development variables, four political variables and several policy measures and found economic resources were more influential in forming State policies than political variables. Parallel to the economists' findings Fry and Winter (1970) also used the conceptmeasurement approach and shifted the debate towards assessing the allocation of the burdens and benefits of State revenue and expenditure policies across income classes. They decided that "political variables were more important than socio-economic ones" (Fry and Winter, 1970: 521). But their analyses were re-examined by Sullvian (1972), Booms and Halldorson (1973) and Fry and Winter's conclusion on political variables was questioned.

Further to the above mentioned models which exist in the literature, Cnudde and McRone (1969), working on party competition and welfare policies in the American States used a liner regression analysis and causal modelling to test the relationship between economic development, party competition and welfare policies. They followed the second major approach which is called the relationship approach to drive the findings.

Thereafter,Sharkansky (1967) on government expenditures and public services in the American States, assessed the relationship between measures of spending and measures of public services using a systems model. Further, Roader (1973) in 'Stability and the Change in the Determinants of State and Local Expenditure' has extended the socioeconomic-political dialogue towards the State-local expenditures considering the factors of socio-economic development and political pluralism. Extending Roader's work, Hwang (1987) researched the 
political versus socio-economic debate on a large number of socioeconomic, political and governmental variables and concluded the dominant role in governmental factors in determination of the local expenditures in Korea. Considering the explanatory variables used in the abovementioned models, peoples' participation, party competition and candidate competition are considered in explaining the political aspect and as an extension to the conventional model which exists in the literature. Explanatory variables such as government service, financial capacity, productivity and intergovernmental fiscal relations are used in this study in explaining the Sri Lankan context.

\section{Studies on the Sri Lankan context}

The number of studies investigating the Sri Lankan reality, both in the central or local governments, is extremely small. Surprisingly, no specific study was found on local governance on a particular aspect. Dilrukshini (2004) has discussed in "Public Expenditure and Economic Growth in Sri Lanka: Cointegration Analysis and Causality Testing" the relationship between public expenditure and national income, using data for Sri Lanka during 1952-2002. According to her, the size of a government in any country depends on several factors, but on political factors rather than market forces.

It is evident from the reviewed literature that these studies still follow the conventional pattern of examining the relative importance of socio-economic and political dominancy. Only a few studies can be seen to broaden the subject matter, considering other aspects, such as institutional, demographic, and geographic factors. Most of these quantitative studies have used different statistical techniques to assess the relative importance of the independent variables. Those are for example simple bivariate correlation, partial correlation, and popularly, multiple regression. It is evident, regardless of the level of government; knowledge on determinants of expenditure is useful for many purposes.

In light of the revealed fact, in the Sri Lankan context, analysis of Sri Lanka expenditure policies has not yet been systematically attempted. Even though a few studies appear in the Asian context, they mostly concern the Korean and Japanese context. Further, it is evident from the reviewed literature that the standard model assumes that differences in local public expenditures across regions can be explained by the differences in per capita incomes, population density, tax base, tax rates, population size, the age structure of the population, grants in-aid, labour market characteristics, and as well as other socio-economic, political, governmental, and institutional factors. 


\section{Development of the Proposed model}

The specification of the proposed model is merely based on the literature review. As explained above three broad approaches are identified from the literature, particularly the socio-economic approach, the political approach and the governmental approach in the context of local government expenditure research. Thereafter, the nature of the socioeconomic, political and governmental characteristics and availability of published data relevant to the municipalities and the urban councils of Sri Lanka as per 2012 are considered.

Further focus of the National Policy on Local Governance was also considered in developing the following proposed model.

$\mathrm{Y}=f$ (Socio-economic Determinants, Political Determinants, governmental Determinants).

More specifically it can be elaborated as follows;

$\operatorname{TOEXP}_{i}=a+b_{1}(S E V)_{i}+b_{2}(P O V)_{i}+b_{3}(G O V)_{i}+u \ldots .$. Equation (1)

In the proposed model ' $a$ ' is the constant term, $b$ are vectors of coefficients on the independent variables, and $\mathrm{u}$ is the normally distributed error term and $i$ represents the specific expenditure category, where TOEXP is the dependant variable of Total Local Government Expenditures and independent variables --SEV ${ }_{i}$ is the socio-economic variable, $\mathrm{POV}_{\mathrm{i}}$ is the political variable and $\mathrm{GOV}_{\mathrm{i}}$ is the governmental variable.

The above model can be further elaborated by discussing the selected variables under each perspective.

TOEXP $_{i}=a+b_{1}(\text { POP })_{i}+b_{2}(\text { EDU })_{i}+b_{3}(\text { HELTH })_{i}+b_{4}(\text { COMEZ })_{i}+b_{5}$ $(\text { PATCI })_{i}+b_{6}(\text { PRTCM })_{i}+b_{7}(\text { PRTCM })_{i}+b_{8}(\text { GOVSE })_{i}+b_{9}$ $(\text { FINEC) })_{i}+b_{10}(\text { FINEC })_{i}+u \ldots \ldots \ldots \ldots \ldots \ldots \ldots \ldots$ Equation (2)

Wherein,

TOEXP $_{\mathrm{i}}=$ Total Expenditure or one of the specific expenditures (road rehabilitation and maintenance, solid waste management, public health, physical planning and infrastructure and other capital expenditure), $\mathrm{POP}=$ Population Density, EDU=Education, HELTH=Health Conditions, COMEZ $=$ Commercialisation, PATCI=Participation, PRTCM $=$ Party Competition CANDI=Candidate Competition, GOVSE=Government Service, FINEC=Financial Capacity, PRODT=Productivity, INTER $=$ Intergovernmental Fiscal Relations 


\section{Major research questions}

(1) What factors - socio-economic, political, and governmental or some combination of all - make the differences in the level of local government expenditures in Sri Lanka?

(2) What actions the local governments can take in promoting the welfare and comfort of the citizens?

\section{Research design}

The dependant variable in this research is considered as the local government expenditure by considering the Fisher (2007) argument and the first dimension of Asher and Van Meter (1973) and Kim (1978). The dependant variable is named as local government expenditure policy in general and measured as per capita total expenditure.

Selection of independent variables is a curtail turning point for any researcher for the success of any research study. In this study dependant variables stem from three dimensions as explained by Hofferbert (1968) and Sharkansky(1968).

Independent variables of a socio-economic perspective are explained as population density, education level, health conditions and commercialisation. Following Holcombe and Williams (2008) and Ladd (1992) and several other scholars, it is assumed that there has to be a positive relationship between the policy and the population and measured as the number of people living in a square kilometre.

Secondly, education is vital in creating human capital. Considering the local governments' control over education, the researcher concerns the number of public schools in the locality to measure the educational characteristics of the jurisdiction. Since the responsibility of local governments is to provide conveniences and well-being to the community, promoting public health has become one of their priorities. Considering the local government's control over the health sector, measurement considers the number of dispensaries and indigenous medical centres in the locality. Commercialisation can be considered as another indicator of socio-economic characteristics of the society. This study concerns the number of local markets to measure the level of commercialisation where most of production and services are enacted.

The second construct, political perspective is mainly based on the views of early political scientists Key and Lockard and this study concerns the 
concepts of political participation, party competition, and candidate competition in explaining the political perspective. Political participation is a key component of democracy. In this regard the researcher concerns the voting turnout ratio considering local government elections across 54 urban local governments in Sri Lanka.

As voter participation, party competition too is central to guaranteeing the efficient working of representative democracies. Taking into account the previous experience in the field in operationalising the political perspective and measured by the party competition index used by Hwang (1987) which is relevant to Sri Lankan situation with multiparty system. This party competition index measures the competition between the ruling party against the allied opposition party group. As aforementioned, according to the political economic theory intercandidate competition as inter party competition positively affects the level of government expenditure. In light of the previous studies the inter-candidate competition was measured by the inter candidate competition rate used by Hwang (1987) as the number of total candidates in terms of the number of total legislative seats.

The first hypothesis on the governmental perspective stems from the government service variable. Dye (1966) has employed the local government service variable in analysing the State and local expenditure. Hwang (1987) has further justified how important the government service variable is in explaining the level of government expenditure. Following the previous studies, in this study, the local government service variable is measured by the total number of local government officers employed in each locality.

The second aspect of the governmental perspective stems from the concern of financial strength of the locality. The consideration of the financial capacity of the local authority is based on previous research findings, particularly the findings of Hwang (1987). In this regard the measurement of the concept concerns the local revenue generation from own sources and measured by the degree of financial self reliance of the relevant authority - that is, the total revenue from own sources as a percentage of total revenue. Since "the local governments have relatively limited revenue sources intergovernmental assistance play a significant role in the governmental finance" (Ahn, 1995, p.1). Thus the relevant measurement is considered as total central government financial transfers in per capita terms.

With regard to the population and the sample of the study, the entire population which consists of all the municipalities and urban 
councils as at year 2012 is considered. In selecting both the units, the urban characteristics of jurisdictions, and similar institutional and administrative structures were considered. The other consideration is based on the concept of self-reliance. In that sense, municipalities and urban councils are more self-reliant than the rural governments of Sri Lanka. All the councils based on 2012 local government elections were considered, and the total was 54 councils. This is a study based on secondary data relevant to the year 2012. Further the Statistical Software Package-SPSS was used to compile and process data, and correlation analysis and Multiple Regression Analysis were used to derive the results.

\section{Findings and discussion}

According to the correlation analysis, all the variables indicate a low correlation except the population density and commercialisation at $\mathrm{r}=.625$; and population density and financial capacity $\mathrm{r}=.515$ and participation and party competition $r=-.598$ at the 0.01 significant level. But however as a whole, according to Pallant (2007) correlation coefficients of this study indicate a lack of multicollinearity.

The results of regression analysis demonstrate a significant correlation among the selected independent and dependant variables as significant at (.000) level with the coefficient of determination $R^{2}$, at 0.647 . Expressed as a percentage, this means that the model explains $64 \%$ of the variance in the local government expenditure policy in general.

\section{Socio-economic determinants of total expenditure}

On socio-economic factors, population density, health status and commercialisation weresignificantinexplaining thetotallocal government expenditure policy in Sri Lanka representing the beta coefficient values of $.187,-.248$ and .188 respectively. The variable population density in the socio-economic cluster depicted the second largest beta coefficient making unique contribution in explaining the total local expenditure policy in Sri Lankan local governments. This supports the general the findings of Holcombe and Williams (2008), the most recent study that looks directly at data on government expenditures to see the relationship between population density and government expenditures.

Secondly the factor commercialisation is significant (Beta $=.188$ ) in socioeconomic cluster, making a unique contribution in explaining the total local expenditure policy in Sri Lankan local governments. This means 
higher the local economic activities due to high production and demand from consumers, there has to be more places declared as local markets. This implies the need to establish and maintain public markets for the need of the inhabitants because as Ponlapat argues, "government is not simply an instrument of a society but plays an important role in shaping public policy and public spending to serve its own interest" (Ponlapat, 2007, p.5). In that sense the relevant circumstances bring governments economic advantages in terms of revenue generation. But on the other side, the second highest beta value indicates governments' responsiveness to the supply-side theories as such, promoting citizens' preferences.

According to the analysis, health conditions of the people were significant ( Beta $=-.248$ ). This means one unit change of community health status lead to -.248 change in total local government expenditure and the relationship is negative. This means that due to the higher health conditions of the community, a lower budget allocation for health services can be expected. Further no statistical significance is found between the educational level and the total local government expenditure.

In light of the discussed research findings the first hypothesis of the research which states local government expenditures vary directly with the socio-economic factors in Sri Lanka is mostly fulfilled.

\section{Political determinants of total expenditure}

On political factors, inter party competition, candidate competition and participation are the selected determinants. From those three, only the participation which was measured in terms of the voting turnout was significant in explaining the total local government expenditure policy in Sri Lanka. The coefficient value of participation (Beta=.112) indicated the third largest value in the equation and made a unique contribution in explaining the total local government expenditure policy in Sri Lanka, when the variance explained by all other variables in the model was controlled. This says that higher the voter participation at an election, higher the total local government expenditure would be. In this regard, this supported the hypothesis that local government expenditures were determined by the degree of participation.

Further the candidate competition and the party competition did not make any statistically significant contribution to the total expenditure equation. This can be justified on the basis of Solé-Ollé (2006). However as a whole, political factors partially supported the hypothesis that local government expenditures are determined by the political factors. 


\section{Governmental determinants of total expenditure}

From the selected governmental variables - government service, financial capacity and intergovernmental fiscal relations - financial capacity of the local government and intergovernmental fiscal relations were significant in explaining the local government expenditure in Sri Lanka. In explaining the total local government policy, the degree of financial self reliance of the locality indicates the significant highest contribution to the model (Beta $=.276$ ). In other words higher the capacity of revenue generation from own sources, larger the volume of services the community can expect.

The next variable which was significant in the cluster of governmental variable is the inter-governmental fiscal relationship which indicated a positive relationship with the total expenditure policy in Sri Lanka. This means that central government transfers makes a unique contribution in explaining (Beta $=.181$ ) the total local expenditure policy in Sri Lankan local governments. These results are consistent with the findings of Kim, (1978) and Hwang (1987).

Although the model suggests a significant relationship between the government service variable and the total expenditure policy on the basis of Niskanen (1971), government service was insignificant in explaining the total local government expenditure policy in Sri Lanka. However as a whole the hypothesis on governmental factors was partly fulfilled.

On the basis of the aforementioned discussion, the revised model in explaining the determinants of local government expenditure in Sri Lanka can be explained as follows;

$$
\begin{aligned}
\text { TOEXP }= & \mathrm{a}+.187(\mathrm{POP})-.248(\text { HELTH })+.188(\text { COMEZ })+.112(\mathrm{PATCI})+ \\
& .276(\text { FINEC })+.181(\text { INTER })+\mathrm{u} . . . . . \text { Equation }(4)
\end{aligned}
$$

Wherein,

$\begin{aligned} \text { TOEX }= & \text { Total Expenditure POP }=\text { Population Density, } \\ & \text { HELTH=Health Conditions, COMEZ=Commercialisation, } \\ & \text { PATCI=Participation, FINEC=Financial Capacity, } \\ & \text { INTER=Intergovernmental Fiscal Relations. }\end{aligned}$

\section{Policy implications}

The main forecast of this study concerns the identification of factors that determine the local government expenditure decision-making in Sri Lanka. What is envisaged from the findings would be as follows: 
Policy makers should equally concern the socio-economic, political and governmental factors, particularly in local government policy making. In this regard, special consideration should be paid to the population size, commercialisation of the area, and the health characteristics of the people. Thus, expansion of public markets brings economic benefits to local governments.. Therefore this can be used as a tool in financing the local governments. In that sense, increasing the number of local markets will support local governments in their self-autonomy. Accordingly, in the long run, facilitation and regulation of markets contribute to the economic development of the country. In that sense this implication brings local policy makers' attention to the fact that power exists in the hands of municipal councils and urban councils to facilitate or regulate economic activities in their jurisdiction towards the country's economic development.

Public participation further should be a tool in expenditure allocation in Sri Lankan localities. This could be an exercise through a bottom up strategy such as the Participatory Budgetary System. This will facilitate promoting need-based development. This positive aspect can be used to further strengthen "People's Governance," as explained under section 4.1.1 of the National Policy on Local Governance. Further, the financial capacity of the locality is the most dominant factor in expenditure decision making in Sri Lanka. In other words, the local government's tax effort is significant. Similarly, expenditure policy is also dependent upon the financial transfers from the central government. This again provides consequential policy implications for 4.1.4.5 of the National Policy on Local Governance. Thus, as stated in the National Policy on Local Governance under section 4.5.2, the participatory budgetary system could be practiced. Moreover, the findings support a favourable environment in which to practice several policy measures in the National Policy on Local Governance through participation, such as participation of women and of marginalized groups (4.4.2), and public-private partnerships (4.5.3) for better service to the public. This will facilitate the promotion of needs-based development.

In addition, the research implications provide fine inputs for the problems underlying the conflicts prevailing in the past. This is because in general ethnic problems and their solutions always have been linked with people's participation in government. This again needs to come to the attention of policy makers in order to overcome the problems which are still not solved and have to be addressed in terms of fiscal allocation related to the conflicts which were there in the northern part of the country. 


\section{Acknowledgement}

The researcher wishes to thank Professor Ponlapat Buracom, Graduate School of Public Administration, National Institute of Development Administration (NIDA) for his great support and advice to accomplish this study.

\section{References}

Asher, H. B., \& Van Meter, D. S. (1973). Determinants of public welfare policies: a causal approach. Sage Publications (CA).

Ahlin, Å., \& Johansson, E. (2001). Individual demand for local public schooling: Evidence from Swedish survey data. International Tax and Public Finance, 8(4), 331-351.

Booms, B. H., \& Halldorson, J. R. (1973). The politics of redistribution: A reformulation. American Political Science Review, 67(03), 924-933.

Cnudde, Charles F. and McRone, Donald J. (1969). Party Competition and welfare Policies in the American States. American Political Science Review, Vol 63, September

Democratic Socialist Republic of Sri Lanka, Parliament, Urban Councils Ordinance (Chapter 255) (Incorporating amendments up to $16^{\text {th }}$ April, 1987) of 1988, Department of Government Printing, Sri Lanka

Democratic Socialist Republic of Sri Lanka, Parliament, Municipal Council Ordinance and Amendment Act 1987, Department of Government Printing, Sri Lanka

Department of Census and Statistics. (2013). Statistical Abstract of the Democratic Socialist Republic of Sri Lanka. Colombo. Ministry of Finance and Planning.

Dilrukshini, W. A. (2004). Public Expenditure and Economic Growth in Sri Lanka: Cointegration Analysis and Causality Testing. Staff Studies, 34(1), 51-68.

Downs G. \& Rocke, D.D. (1979). Bureaucracy and Juvenile Corrections in the States. Policy Studies Journal, Vol 07, No 4 Summer. 721-728

Dawson, R. E. \& Robinson, J. R. (1963). Interparty Competition, Economic Variables and Welfare Policies in American State. The Journal of Politics. 25: 265-289.

Dye, Thomas R. (1966). Politics, Economics and the Public: Policy Outcome in the American States. Chicago: Rand McNally.

Kurnow, E. (1963). Determinants of state and local expenditures reexamined. National Tax Journal, 252-255.

Fabricant, S. (1959). Basic facts on productivity change (No. 63). New York, NY: National Bureau of Economic Research.

Fabricant, S., \& Lipsey, R. E. (1952). The trend of government activity I $n$ the United States since 1900. NBER Books.

Fernandez, R., \& Rogerson, R. (1997). The determinants of public education expenditures: evidence from the states, 1950-1990 (No. w5995). National Bureau of Economic Research. 
Fry, Brian R., \& Winters, Richard F. (1972). The Politics of Redistribution. American Political Science Review. Vol. 66 December.

Fisher, Ronald .C. (2007). State and Local Public Finance. Thomson-South-Western.

Gabler, L.R., \& Brest, J.I. (1967). Interstate Variations in Per Capita Highway Expenditures. National Tax Journal , XX(1), 78-85

Hwang Y. W. (1987). An analysis of Local Government Expenditures in a Developing Country: The Case of Centralized Korea. PhD Dissertation. University of Pittsburgh.

Holcombe R. G. \& Williams De Edgra W. (2008).The Impact of Population Density on Municipal Government Expenditures Public Finance Review; Volume 36 No: 3, May, 359-373

Hofferbert, Richard I. (1966). Ecological Development and Policy Change in the American States. Midwest Journal of Political Science. 10 (November):164.

Key, V. O. (1956). American state politics: An introduction. New York: Knopf.

Kim H.S. (1978). An Analysis of National Aid and Prefectural Expenditure in Japan, PhD Dissertation. Florida State University.

Ladd, Helen. (1992). Population Growth, Density and the Costs of Providing Services. Urban Studies. 29 (2): 273-295.

Lockard, D. (1963). New England State Politics. Princeton: Princeton University Press.

Matteo L.D \& Matteo R.D. (1998). Evidence on the Determinants of Canadian Provincial government Health Expenditures: 1965-1991. Journal of Health Economics. 171998. 211-228

Niskanen, W.A. 1971. Bureaucracy and Representative Government, Aldine-Atherton, Chicago, IL,

Painter, G \& Bae, K.( 2001). The Changing Determinants of State Expenditure in the United States: 1965-1992, Public Finance and Management. 1, (4), 370-392.

Poterba, J. (1996). Demographic Structure and the Political Economy of Public Education. Journal of Public Policy and Management, 16, 48-66.

Ponlapat Buracom (2007). Explaining the Growth of Public Spending in Thailand: Demand-side, Supply-side Explanations and Empowerment, NIDA Development Journal, Vol.47.

Roader, P. W. (1973). Stability and the Change in the Determinants of State and Local Expenditure. Doctoral dissertation, The Florida State University.

Sacks , S \& Harris, R.(1964). The Determinates of State and Local Government Expenditures and Intergovernmental flows of Funds. The National Tax Journal, XVII(1), 75-85.

Sharkansky, I. (1968). Agency requests, gubernatorial support and budget success in state legislatures. American Political Science Review, 62(04), 1220-1231.

Sharkansky, Ira \& Hofferbert, Richard I. (1969). Dimensions of State Politics, Economics, and Public Policy. American Political Science Review. Vol. 63. 867-879 September. 
Sol`e-Oll'e, A. (2005). Expenditure Spillovers and Fiscal Interactions: Empirical Evidence from Local Governments in Spain. Barcelona, Institutd'Economica de Barcelona. (Working paper 2005/3)

Sullivian, John L. (1972). A Note on Redistributive Politics. American Political Science Review, 68, 1301-1305

Sjoquist, D.L. (1982). The Effects of the Number of Local Governments on Central City Expenditures. The National Tax Journal, XXXV, 79-87

The Gazette of the Democratic Socialist Republic of Sri Lanka. (2009). National Policy on Local Government, Democratic Socialist Republic of Sri Lanka.

Weicher, John C. (1972).Determinants of Central City Expenditures: Some Overlooked Factors and Problems. National Tax Journal , December,23, 379-96. 